\title{
11
}

\section{Integrity in Learner-Centered Teaching}

\section{Douglas Robertson}

Eastern Kentucky University

Learner-centered teaching challenges teachers with inherent conflicts and can be viewed as a conflicted educational helping relationship. This chapter explores fundamental conflicts in learner-centered teaching as well as ways to handle them constructively. Learner-centered teacher integrity is seen as the degree to which contradictory demands on the teacher (e.g., facilitating learning as well as evaluating it) are brought into synergistic relationship. A process for enhancing these synergies is suggested. This discussion emerges from a line of work that attempts to further develop the learner-centered teaching role in higher education (Robertson, 1996, 1997, 1999a, 1999b, 2000a, 2000b, 2000c, 2001).

The test of a first-rate intelligence is the ability to hold two opposed ideas in the mind at the same time, and still retain the ability to function.

-Fitzgerald (1945, p. 69)

\section{INTRODUCTION}

Tearner-centered teaching requires the kind of intelligence that Fitzgerald (1945) mentions. It does so, in part, because the role of the lcarncr-centered teacher has within it fundamental conflicts. For example, learner-centered teachers must serve as both facilitators and evaluators, if not simultaneously, then at least in uncomfortably close, semporal proximity, as in, "Tell me what you think ... and forget that I'm grading you." Learner-centered teaching constitutes what could be called a conflicted helping relationship (Robertson, 1996,2000 a, 2000b). Conflict denotes contention, antagonism, incompati- 
bility, or contradiction; paradox indicates things that appear contradictory but are nonetheless true. I think that to which Fitzgerald refers above is paradox, or being able to function within the context of things that seem antagonistic and incompatible but go together even so. Learner-centered teaching urges us to transform conflict that is inherent in this educational helping relationship into paradox.

Some everyday teacher questions motivated my exploration of conflict in learner-centered teaching: How can I give a student whom I have been mentoring a " $D$ " on an exam and still have the student's trust? How can I deal with the many demands for my time and passion-my love of my own learning, my love of the subject, my love of the students and their learning? How do I go on with the material for the group because I know that most of them are ready and $I$ know that we must but I also know that I am leaving a few individuals behind, perhaps forever? How do I harden my heart but keep it soft? How do I keep up with my subject area and also learn about teaching and learning? How do I care for myself and for my students at the same time? The following chapter answers each of these different questions with the same answer: I must transform conflict into paradox and thereby enhance my teacher integrity.

This chapter identifies some fundamental conflicts in the learner-centered teaching role and explores ways of achieving integrity (or paradox) in this conflicted educational helping relationship. Building on an extensive analysis of pertinent research, theory, and practice, this discussion emerges from a line of work that attempts to contribute to the further conceptualization and professionalization of the learner-centered teaching role in colleges and universities (Robertson, 1996, 1997, 1999a, 1999b, 2000a, 2000b, 2000c, 2001).

\section{LITERATURE REVIEW}

Scholarship on role conflict and successful coping in collegiate teaching and learning contexts has concentrated primarily on students, especially returning adult students with their notorious multiple role responsibilities (e.g., Anderson \& Miezitis, 1999; Clouder, 1997; Harvey, \& Wiebe, 1997; Home, 1998; Mallinckrodt \& Leong, 1992; McBride, 1997; Mikolaj \& Boggs, 1991; Widoff, 1999). Some scholarship has addressed conflicts within the overall professor role, especially those involving research versus teaching (c.g., Burroughs, 1990; Holly, 1990; Stark, 1986; Weimer, 1997; Wong, 1995). However, with a few exceptions (e.g., Palmer, 1998), little work appears to have focused on 
inherent conflicts in the work of professors-as-teachers, much less on how to handle those conflicts constructively.

\section{Conflicts in Learner-Centered Teaching}

The following five antagonisms serve to illustrate the conflicted nature of the educational helping relationship, or learner-centered teaching. These fundamental conflicts occur to me when I reflect on my teacher work. Readers should feel free to add and delete as they see fit.

\section{Facilitator Versus Evaluator}

Facilitator. As a facilitator of student learning, the learner-centered teacher is devoted to specific people who show up at the party (or enroll in the course). Learner-centered teachers teach students not subjects. They attend to those specific students' abilities and disabilities, experience or lack of experience; personality; learning style; gender, race, and class socialization; rhythms; learning traumas; and so forth. They attempt to help individuals to progress vis-a-vis the course objectives from where they entered the course to where they exit the course, regardless of where they started, how fast they progressed, or how far. Many learner-centered teachers even hope that the students develop overall as persons as well. The learner-centered teacher (an educational helping professional) is devoted to the students' learning and development.

Evaluator. As an evaluator of student learning, the learner-centered teacher represents a variety of constituents besides the individual learners. These other constituents may often have different agendas than the learners. Their agendas usually relate to maintaining standards and the meaning of course credit and degrees within various communities, while the students' agendas are much more personalized. Learner-centered teachers have an obligation to represent the standards of their regional accreditation associations, disciplines, departments, colleges, universities, alumna, and often, surrounding geographical region. Not to sound grandiose, teachers who issue grades in accredited institutions have a lot of company in their heads as they decide the grading fate of individual students.

Conflict. The learner-centered teacher must gain the trust from individual learners that a viable helping relationship requires while at the same time rendering for external communities summative evaluations that may be damaging to individual learners and their academic progress. 


\section{Loving the Subject (Teacher Learning) Versus Loving the Students (Student Learning)}

No wonder teaching was called an art, the most difficult kind of art in which the final expression depends upon a delicate and dangerous balance berween two people and a subject. Eliminate the subject and the whole center collapses... (Sarton, 1961, p. 213)

Teacher learning. The educational helping relationship exists because the learner wants help learning a subject (Robertson, 2000b). Without the subject, the relationship ceases to have meaning and purpose, and it feels weird (Sarton, 1961). I admit that one of the things that attracted me about college teaching is that it required (I would say allowed, even promoted) me to keep learning. I love learning about things that interest me. It puts a spring in my step. If I have to stop, I can't wait to get back to it. I feel eternally grateful that I get paid to do something that I love so much.

Student learning. While my subject expertise plays a critical role in student learning, often it needs to be reined in so that I can serve as an effective educational helping professional. For example, students learn better with prompt and rich feedback vis-à-vis their active use of that which is to be learned. As a learner-centered teacher, my love of student learning requires me to plan into my schedule as much, or more, time to create active learning opportunities for students and to provide feedback to them about their learning as I include for my own ongoing learning of the subject.

Conflict. Learner-centered teachers must love their own subject learning and their students' subject learning simultaneously and equally, a challenge that expresses itself most tangibly in decisions about how teachers spend their time.

\section{Subject Expert Versus Teaching and Learning Expert}

Subject expert. As just discussed, the college teacher-learner-centered or not-is expected to be a subject expert. The pressure to keep up with one's subject comes from many sources outside of the self. Our colleagues, our administrators, our professional communities, our proximate geographical communities, our alumnae, those same students that want us to attend to them and only them, all want us to know our stuff.

Teaclsing and learning expert. Learner-centered teachers take on another subject besides their discipline. They define teaching as facilitating learning, which necessitates adding the subjects of what learning is and how it can best be facilitated to one's existing subject specialties. 
Conflict. As mentioned previously, learner-centered teachers must deal with the conflict between their own learning and their students' learning. Additionally, with limited time and energy allocated to their own subject learning, learner-centered teachers add a competitor to their disciplinary subjects-namely, the subject of teaching and learning. Again, this conflict reveals itself most concretely in teachers' resource management (e.g., time and money allocations, which conferences or sessions to attend, which books and journals to read, and so forth).

\section{Caring for Students Versus Caring for Self}

Caring for students. Learner-centered teachers devote themselves to students as related to the students learning the subject. They care about the students, their abilities, experience, rhythms, potential, and welfare.

Caring for self. Learner-centered teachers must care for themselves so that they do not exhaust the fundamental resource that cares for the students (themselves). In an airline emergency, when oxygen masks are required, parents must remember that it is not a selfish act, but a vitally caring act, for them to put the mask on themselves first in order to care best for their children. In teaching, something similar is true: Teachers must care for themselves in order to care for the students. In addition, teachers are in a position to model healthy self-esteem and healthy caring. The way in which they care for students and for themselves may be one of the most important lessons that they have to teach.

Conflict. Like practitioners of any helping profession, learner-centered teachers have to care simultancously for themselves and for their students. The exhausted teacher says, "If I read one more student essay, l'll scream!" and decides to rejuvenate with an afternoon devoted to her or his own work instead. Often, like so many of the learner-centered teachers' conflicts, the struggle is expressed in a competition for time, energy, and other teacher resources. In studying the development of caring, Gilligan (1982) theorized that developmental perspectives arranged themselves into three progressions, beginning with a focus on the self, shifting to a focus on the other, and resolving to a simultancous focus on the welfare of self and other. Learner-centered teachers face this developmental press.

\section{Individual Mentor Versus Group Learning Leader}

Individual mentor. Learner-centered teachers practice a respect for diversity (writ large) that expresses itself as a devotion to each and every student's 
learning, not student learning as some kind of aggregate abstraction. I focus on individual abilities, experience, and rhythms. I try to mentor individuals.

Group learning leader. As a member of the teaching and learning system, teachers are learning leaders. They have the formal authority and responsibility to make decisions for the group regarding what to do, when to do it, and so forth.

Conflict. Learner-centered teachers can individualize courses, build in optimal flexibility, and respect difference in all ways. Notwithstanding this dedicated devotion to individual students progressing in different ways and rhythms, learner-centered teachers must sometimes make decisions on behalf of the group that they know will result in leaving an individual student behind while at the same time trying to mentor that individual student.

\section{Exercise}

Brainstorm. What conflicts do you experience as a teacher-conflicts that seem to go with that role for you?

Evaluate. How central (important) is that conflict to your work as a teacher? Rate each conflict in terms of its centrality, 1 to 5, low to high.

Share. Ask a colleague (or several colleagues) to do the same and explore your responses together.

\section{Approaches to Conflicting Demands}

Building on role theory (Goode, 1960; Levinson, 1959), empirical research on handling conflicting role demands suggests that strategies often fall into three categories (Beutell \& O'Hare, 1987; Hall, 1972), which are briefly explained below (Figure 11.1).

Figure 11.1

Three Primary Strategies for Handling Conflicting Role Demands

\begin{tabular}{c|c|c|c}
\hline $\begin{array}{c}\text { Approach to } \\
\text { role demands }\end{array}$ & \multicolumn{2}{|c|}{ Attempt Change } & $\begin{array}{c}\text { Do not } \\
\text { Attempt Change }\end{array}$ \\
\hline $\begin{array}{c}\text { Locus of } \\
\text { control }\end{array}$ & External & Internal & $\begin{array}{c}\text { External or } \\
\text { internal }\end{array}$ \\
\hline Strategies & $\begin{array}{c}\text { Negotiate } \\
\text { with others }\end{array}$ & $\begin{array}{c}\text { Negotiate } \\
\text { with self }\end{array}$ & React \\
\hline
\end{tabular}




\section{Negotiate with Others}

I can address the conflicting demands overtly with people making the demands and collaborate to find new, more compatible role responsibilities. Also, I can cooperatively define different levels of acceptable performance in areas of role responsibilities.

\section{Negotiate with Self}

I can do with myself as I do with others, namely, redesign role responsibilities or acceptable levels of performance. I can change conception of the roles and then work to accept a less than perfect, but still excellent, performance in those roles.

\section{Just React}

I can avoid changing anything (role responsibilities or acceptable levels of performance) except my effort-that is, just try harder. The data suggest that this strategy may work in the short term, but over the long haul, it leads to burnout. A combination of the first two strategies-negotiating with self and others-appears to be the healthiest and most effective long-term strategy (Hall, 1972).

\section{Exercise}

Focus. Review the conflicts that you identified as central to your work as a teacher, and pick one.

Visualize. Imagine how you typically deal with that conflict.

Evaluate. What's good and not so good about your typical response.

Share. Request a colleague (or several) to do the same and discuss your responses together.

\section{LEARNER-CENTERED TEACHER INTEGRITY}

I began preparing this chapter thinking about conflict and coping and came to realize that I was really interested in paradox and harmony. Words and images matter, and briefly exploring these, and related, words (s.v., Webster, 1966) leads to a useful conceptualization-a continuum of learner-centered teacher integrity.

\section{Conflict, Coping, Managing}

Conflict, cope, and manage come from words that have to do with clashing, hitting, and controlling through force. These words imply forcefully overcoming antagonisms, subduing them, repressing their tension. This approach, 
outcome, and connotation are not what I had in mind as the optimal approach to the conflicted helping relationship that is learner-centered teaching.

\section{Paradox, Harmonizing, Synergizing, Integrating}

Words such as paradox, harmony, synergism, and integrate come from words that involve joining things together (in particular, things that appear incompatible) in ways that create entities that are more complete and significantly more empowered than before the joining. This approach, outcome, and connotation is, most certainly, what I had in mind as describing those occasions when I sense that I am functioning honestly and optimally as a learner-centered teacher.

\section{Continuum of Learner-Centered Teacher Integrity}

I began to realize that these words relate to different positions along a continuum that expresses the degree to which learner-centered teachers are integrating antagonistic role demands and transforming potentially paralyzing conflicts into generative paradox (Figure 11.2).

\section{Figure 11.2}

\section{Learner-Centered Teacher Integrity}

\begin{tabular}{|c|c|c|}
\hline LOW & & HIGH \\
\hline $\begin{array}{l}\text { Disintegrating, not } \\
\text { coping with conflicts, } \\
\text { falling apart. For ex- } \\
\text { ample, abdicating the } \\
\text { role of learner-cen- } \\
\text { tered teacher and see- } \\
\text { ing oneself as a master } \\
\text { learner who dissemi- } \\
\text { nates information and } \\
\text { determines the degree } \\
\text { to which that teacher- } \\
\text { centered information } \\
\text { is learned by students. }\end{array}$ & $\begin{array}{l}\text { Coping with conflicts, } \\
\text { managing, surviving. } \\
\text { For example, com- } \\
\text { partmentalizing roles, } \\
\text { as in now I am going } \\
\text { to put on my grading } \\
\text { hat, and now I have } \\
\text { my facilitator hat on. }\end{array}$ & $\begin{array}{l}\text { Integrating conflicts, } \\
\text { synergizing solutions, } \\
\text { achieving paradox. } \\
\text { For example, intro- } \\
\text { ducing students to the } \\
\text { facilitator/evaluator } \\
\text { conflict and asking } \\
\text { them how they would } \\
\text { deal with it. }\end{array}$ \\
\hline
\end{tabular}

Low integrity. In this state, the teacher is not resolving contradictory pulls and pushes very well. The frustrated teacher may say, "To heck with it! Who 
has time for this grief?" This lack of resolution may lead to a complete disintegration of the learner-centered perspective, which is then replaced by the default college teaching perspective-teacher-centeredness.

Medium integrity. The learner-centered teacher may get contradictory roles and responsibilities to coexist, but not integrate, by techniques such as compartmentalizing. In this instance, the conflicting demands may be satisfied but not at the same time. Metaphorically, teachers use "hat talk," as in putting on my grading hat or my facilitator hat, for example. The teacher and students may not feel much resolution or energy from this approach, but it is workable and generally acceptable to teachers and students. Its effect on the teaching and learning environment is less than optimal because the consequences of teacher behaviors (such as grading) cannot be stopped simply by overtly changing the prevailing metaphor.

High integrity. Optimally, the teacher may achieve a resolution of conflicting demands that creates important synergies. For example, I bring the facilitator versus evaluator conflict into the classroom overtly in the first class meeting as a part of explaining the orientation of the course and my teaching philosophy to the students. I explain how I have tried to work with the conflict, and $I$ invite them to enter a teacher's frame of reference and imagine how they would deal with it. Sometimes some great ideas result and sometimes they do not. Regardless, entering the teacher's frame of reference not only helps the students to understand (and often own) the grading system, it also has a developmental press for them. It encourages them not only to see situations from a variety of perspectives but also to take increasing responsibility for being an authority themselves and directing their own learning. A synergy is created. The conflicts resolve themselves, and cognitive development results. A generative paradox is achieved.

\section{STEPS TOWARD INTEGRTY}

The question becomes how do we achieve this high level of integrity-these synergistic harmonies arising from seemingly contradictory demands, these generative paradoxes? Parker Palmer (1998), one of the few authors to write about the vital role that paradox plays in college teaching, says that we must tap a larger love:

If we are to hold paradoxes together, our own love is absolutely necessary-and yet our own love is never enough. In a time of tension, we must endure with whatever love we can muster until that very tension draws a larger love into the scene. (p. 85) 
According to Palmer (1998), how we get that larger love is to wait and to suffer:

There is a name for the endurance we must practice until a larger love arrives: it is called suffering. We will not be able to teach in the power of paradox until we are willing to suffer the tension of opposites, until we understand that such suffering is neither to be avoided nor merely to be survived but must be actively embraced for the way it expands our own hearts. (p. 85)

Regarding the significance of the need to be able to sit with tension, to endure discomfort, to be patient, to persist, I am in complete agreement with Palmer. In addition, I think that we can do things to facilitate the process of achieving integrity, of creating synergies, and of experiencing that larger love (Figure 11.3).

Figure 11.3

Steps Toward Learner-Centered Teacher Integrity

\begin{tabular}{ll}
\hline Step & Task \\
\hline Identification & $\begin{array}{l}\text { Identify specific conflict and sources of conflicting demands } \\
\text { in self and environment }\end{array}$ \\
\hline Intervention & $\begin{array}{l}\text { Negotiate with self and environment toward harmony, syn- } \\
\text { ergy (adjust expectations, create alternatives, reach accord) }\end{array}$ \\
\hline Integration & $\begin{array}{l}\text { External and internal force field analysis, identify forces of } \\
\text { harmony and discord (integration and disintegration, barri- } \\
\text { ers and supports), enhance forces of harmony, diminish } \\
\text { forces of discord }\end{array}$ \\
\hline
\end{tabular}

\section{Identification}

Our first task is to accept the conflict and to identify it. Denial of conflict may interfere with the work of this phase. (For purposes of illustration, we continue with the common facilitator versus evaluator conflict throughout this discussion of the process's three phases.) In groups of college teachers, when I bring up the facilitator versus evaluator conflict, normally heads start nodding in agreement, that particular tension being so ubiquitous among college 
teachers. Sometimes, one professor will argue that she or he does not experience a conflict among those functions. However, it soon becomes clear that the person does feel the conflict but simply does not want to call it one. For whatever reason, teachers may defend themselves psychologically through denial of conflict. We need to accept that our chosen teaching perspectivelearner-centered teaching - has conflict inherent in it, and we need to be alert to identifying the most outstanding conflicts in our own particular teaching practice. We then need to identify the primary sources of the conflicting role demands. For example, in the conflict between the roles of facilitator and evaluator, who or what is asking us to behave as a learning facilitator and defining for us the specific expectations for that role? The same question can be asked for the role of evaluator.

Facilitator. We may have within our own minds a well-developed exemplar of the learning facilitator with which we compare ourselves. We may participate in professional communities, both directly and through print and electronic media, that have as the bedrock of their discourse facilitator exemplars such as Belenky, Clinchy, Goldberger, and Taurle's midwife(1986), Brookfield's skilled teacher (1990), Daloz's mentor (1986), Freiere's partner (1993), Knowles's andragogue (1975, 1989; Knowles \& Associates, 1984), or Mezirow's emancipatory educator (1991). We may have departmental colleagues with whom we interact on a daily basis who articulate frequently exemplary images of college teachers as learning facilitators. Chairs, deans, provosts, and faculty development professionals may be sending messages to us that communicate the value of focusing on facilitating individual student learning rather than disseminating knowledge to the undifferentiated student masses. Students who have acquired a taste for instructional strategies that utilize active learning and a facilitative teaching paradigm may send the facilitator role demands to us.

Evaluator. Who is creating the expectation that we act as a learning evaluator? We can usually begin with ourselves. We carry with us into our college teaching at least 20 years of experience as a student in graded learning environments where it was the teacher's responsibility to evaluate our progress and render a grade. We expect of ourselves when we become the teacher to grade student performance. Students expect that of us as well. They have at least 12 years of experience in graded learning environments which has taught them that grading is an important part of what a teacher does, like it or not. Faculty colleagues, chairs, deans, provosts, and a whole bevy of other administrators, all expect us to serve as an evaluator. Some of them may even complain regularly in public and private about grade inflation and the dumbing down of the curriculum. Professional associations may rank institutions and programs 
based on reputation, and these rankings may affect not only our pride but also our funding, publication, and career advancement opportunities. Accreditation associations pay attention to our evaluation systems and results, and their messengers within our own institutions remind us of this fact regularly. The community in which we live talks about our institution, and we would like for them to convey respect for it. This ambient chatter sends messages to us regarding our need to be a responsible evaluator in our courses and to hold high our standards. The university's alumni want us to make sure that the value of their degrees are not eroded by lackadaisical, undemanding grading.

\section{Intervention}

Negotiate with self. The images that I have of the exemplary college teacher - the caring facilitator of individual student learning-may not be realistic, given the need to serve also as an evaluator of individual student learning. My image of the exemplary college teacher may be incomplete in the sense that it oscillates between images of either an exemplary facilitator or of an exemplary evaluator. I need to create an image of both together. Furthermore, I need to adjust the expectations that I am imposing on myself with regard to this synthesis. The exemplary image of the facilitator/evaluator cannot realistically involve the perfect expression of each conflicting role put together. I cannot expect myself to fulfill the purest image of each. I must become comfortable with this new exemplary image and set of expectations for myself.

Negotiate with others. In the information field that I inhabit, who is sending me the most important messages about my function as a facilitator and evaluator? One of the most constant and significant senders of role demands are the students. That means I need to negotiate with them. But I do not need to merely call the conflict to their attention. I need to invite them to enter the conflict from my perspective and to struggle with what they would do. I need to present my solution and request their response. This kind of process not only helps the students and the teacher to understand and share the same expectations for the teacher, it also stimulates development in the students by role playing the position of the formal authority in the learning environment.

\section{Integration}

Self. The work of the integration phase is to adapt to the ripple effects of whatever new was negotiated in the intervention phase and to take explicit actions to enhance supports of the novelty and to diminish hindrances (Robertson, 1988). In the locus of the self, we need to explore how the parts of our worldview relate to our conception of what we should be as a teacher. 
For example, is our self-esteem highly invested in us aspiring to be Mother Theresa or Mahatma Gandhi in the classroom? If we change our conception of an exemplary teacher, how does that new conception ripple out through our self-esteem system of beliefs? And so forth. We may, over time, have a tendency to lose a fix on our new conception. Perhaps it would be useful once a week to set aside time to reflect on our sense of integration with regard to conflicts that we see as fundamental to our work as learner-centered teachers, in this case, facilitator versus evaluator.

Environment. In a Peanuts cartoon strip, Linus goes to the door and asks whether his friend still has the drawing that he had made. The person, who had thrown away the drawing, retrieves it from the trash and rolls it out to Linus on the porch, whereupon Linus says, "Great art should never be rolled across the porch...." In the integration phase, we need to steer clear of folks who would roll our newfound integrity across the porch. We need to scan our environment for supports and hindrances of our new role definitions and expectations. Perhaps we should seek a consultative, confidential relationship with a colleague or faculty development professional in order to garner support for processing the ripple effects of our new image of learner-centeredteacher-as-facilitator/evaluator. Perhaps this would be a good time to reduce contact with colleagues who seem especially adept at finding flaws in our teaching philosophy and getting our goat.

\section{Conclusion}

Without Contraries there is no progression -Blake (1963, p. 3.)

Perhaps what Blake (1963) had in mind was the possible synergies, the generative potential that comes from bringing contraries into harmony. Our discussion has explored this topic within the context of learner-centered teaching. We have examined conflicts that are fundamental to learner-centered teaching (at least for me); reviewed the scholarship on strategies for handling conflicts; explored the relationship between how we handle conflicts and the degree to which we have achieved teacher integrity, as expressed by a learner-centered teacher integrity continuum; and considered a method for enhancing our teacher integrity. The larger objectives of this discussion have been to help classroom teachers with this thorny problem of conflicting role demands as well as to develop further the conceptualization of college-level, learner-centered teaching. 


\section{REFERENCES}

Anderson, B. J., \& Miezitis, S. (1999). Stress and life satisfaction in mature female graduate students. Initiatives, 59(1), 33-43.

Belenky, M. F., Clinchy, B. M., Goldberger, N. R., \& Tarule, J. M. (1986). Women's ways of knowing: The development of self, voice, and mind. New York, NY: Basic Books.

Beutell, N. J., \& O'Hare, M. M. (1987). Coping with role conflict among returning students: Professional versus nonprofessional women. Journal of College Student Personnel, 28 (2), 141-145.

Blake, W. (1963). The marriage of heaven and hell. Coral Gables, FL: University of Miami Press.

Brookfield, S. D. (1990). The skillful teacher: On technique, trust, and responsiveness in the classroom. San Francisco, CA: Jossey-Bass.

Burroughs, C. B. (1990). The new professionalism: Teaching and/or scholarship. Liberal Education, 76 (5), 14-17.

Clouder, L. (1997). Women's ways of coping with continuing education. Adult Learning, 8(G), 146-148.

Daloz, L. A. (1986). Effective teaching and mentoring: Realizing the transformational power of adult learning experiences. San Francisco, CA: Jossey-Bass.

Fitzgerald, F. S. (1945). The crack-up. New York, NY: New Directions.

Freire, P. (1993). Pedagogy of the oppressed (rev. ed., M. B. Ramos, Trans.). New York, NY: Continuum.

Gilligan, C. (1982). In a different voice: Psychological theory and women's development. Cambridge, MA: Harvard University Press.

Goode, W. J. (1960). A theory of role strain. American Sociological Review, 25 (4), 483-496.

Hall, D. T. (1972). A model of coping with role conflict: The role behavior of college educated women. Administrative Science Quarterly, 17(4), 471-486.

Harvey, C. D., \& Wiebe, B. S. (1997). "I'm going to make the effort": How mothers become successful university students. Canadian Home Economics Journal, 47 (4), 155-159.

Holly, C. (1990). The new professionalism: Changes and challenges. Liberal Education, 76(5), 17-19. 
Home, A. M. (1998). Predicting role conflict, overload and contagion in adult women university students with families and jobs. Adult Education Quarterly, 48, 85-97.

Knowles, M. S. (1975). Self-directed learning: A guide for learners and teachers. Chicago, IL: Association/Follett.

Knowles, M. S. (1989). The making of an adult educator: An autobiographical journey. San Francisco, CA: Jossey-Bass.

Knowles, M. S., \& Associates (1984). Andragogy in action: Applying modern principles of adult learning. San Francisco, CA: Jossey-Bass.

Levinson, D. J. (1959). Role, personality, and social structure in the organizational setting. Journal of Abnormal and Social Psychology, 58 (2), 170-180.

Mallinckrodt, B., \& Leong, F. T. (1992). Social support in academic programs and family environments: Sex differences and role conflicts for graduate students. Journal of Counseling and Development, 70 (6), 716-723.

McBride, M. C. (1997). Counseling the superwoman: Helping university women cope with multiple roles. Guidance and Counseling, 12, 19-23.

Mezirow, J. (1991). Transformative dimensions of adult learning. San Francisco, CA: Jossey-Bass.

Mikolaj, E. L., \& Boggs, D. L. (1991). Intrapersonal role conflicts of adult women undergraduate students. Journal of Continuing Higher Education, 39 (2), 13-19.

Palmer, P. J. (1998). The courage to teach: Exploring the inner landscape of a teacher's life. San Francisco, CA: Jossey-Bass.

Robertson, D. L. (1988). Self-directed growth. Muncie, IN: Accelerated Development.

Robertson, D. L. (1996). Facilitating transformative learning: Attending to the dynamics of the education helping relationship. Adult Education Quarterly, 47(1), $41-53$.

Robertson, D. L. (1997). Transformative learning and transition theory: Toward developing the ability to facilitate insight. Journal on Excellence in College Teaching, $8(1), 105-125$.

Robertson, D. L. (1999a). Unconscious displacements in college teacher and student relationships: Conceptualizing, identifying, and managing transference. Innovative Higher Education, 23 (3), 151-169.

Robertson, D. L. (1999b). Professors' perspectives on their teaching: A new construct and developmental model. Innovative Higher Education. 23 (4), 271-294. 
Robertson, D. L. (2000a). College teaching as an educational helping relationship. Toward the Best in the Academy, 13 (1).

Robertson, D. L. (2000b). Enriching the scholarship of teaching: Determining appropriate cross-professional applications among teaching, counseling, and psychotherapy. Innovative Higher Education, 25 (2), 111-125.

Robertson, D. R. (2000c). Professors in space and time: Four utilities of a new metaphor and developmental model for professors-as-teachers. Journal on Excellence in College Teaching, 11 (1), 117-132.

Robertson, D. R. (2001). Beyond learner-centeredness: Close encounters of the systemocentric kind. Journal of Faculty Development, 18(1), 7-13.

Sarton, M. (1961). The small room. New York, NY: Norton.

Stark, J. S. (1986). Administrator and faculty views of scholarly performance. New Directions for Institutional Research, No. 50, 59-74.

Webster's third new international dictionary of the English language, unabridged. (1966). Springfield, MA: Merriam.

Weimer. M. (1997). Integration of teaching and research: Myth, reality, and possibility. New Directions for Teaching and Learning. No. 72, 53-62.

Widoff, J. C. (1999). The adult male undergraduate student experience: Real men do return to school. Journal of Continuing Higher Education, 47(2), 15-24.

Wong, E. D. (1995). Challenges confronting the researcher/teacher: A rejoinder to Wilson. Educational Researcher, 24 (8), 2-23. 


\section{Contact:}

Douglas Reimondo Robertson

Professor and Director

Teaching and Learning Center

Eastern Kentucky University

2 Keen Johnson Building

521 Lancaster Avenue

Richmond, KY 40475

Voice (859) 622-6517

Fax (859) 626-6518

Email douglas.robertson@eku.edu

Douglas Reimondo Robertson is Professor of Geography and Educational Leadership and founding Director of the Teaching and Learning Center at Eastern Kentucky University. He has published 35 scholarly articles, most recently on college teaching and learning, as well as a well-received book on intentional change in adult life which has entered its third printing (Self-Directed Growth). Dr. Robertson has helped to start three university faculty development centers and has served as the founding director at two of them. He serves as Senior Editor for the New Forums Press Book Series on Practices for Better Teaching, as well as on the Editorial Board of the Journal on Excellence in College Teaching. Also, he reviews manuscripts for Innovations in Higher Education and To Improve the Academy. Dr. Robertson has provided over 100 trainings, consultations, and speeches to a wide variety of educational, business, governmental, human service, and health care organizations. His current scholarship focuses on building two interrelated theories-a developmental model of professors-as-teachers and a conceptualization of college teaching as an educational helping relationship. He taught his first college course in 1971. 